\title{
Effects of soil and environmental factors on the site productivity of pure Oriental beech forests in Akkuş region of Turkey
}

\author{
Murat YILMAZ \\ Soil Science and Ecology Dept., Faculty of Forestry, Karadeniz Technical University, 61080, Trabzon, Turkey
}

Corresponding author: yilmaz61@ktu.edu.tr

\begin{abstract}
Oriental Beech grows naturally in the Eastern Caucasus, Northern Iran and, Crimea, from the west of the Balkans towards Anatolia. Akkuş Region of Turkey is one of the moist ecosystems where this tree species spread optimally. In this spread area, the change in local site factors affects site productivity. In this study, the correlations between the height growth of pure Oriental beech forests between 1200-1500 m altitudes in Akkuş region and some soil characteristics and location factors were investigated. 40 sample plots were taken from normally covered Oriental beech stands. In the sample plots, soil profiles were dug and soil sampling was performed according to genetic soil horizons. The location factors of the sample plots in the field were determined, and $\mathrm{d}_{0.30}$ diameter, $\mathrm{d}_{0.30}$ age, and upper height were measured in 4-6 trees with upper stand height. The site productivity (site index) was determined based on the correlation between standard age and upper stand height. Physical and chemical soil analyses were performed in the soil samples taken.

The correlations between the productivity indexes (site index) of the sample plots and the local ecological characteristics of the site were tested by correlation analysis. Positive correlations were determined between site index and the land slope degree and altitude (respectively $\mathrm{p}<0.05, \mathrm{r}=0.438 ; \mathrm{p}<0.05, \mathrm{r}=0.211$ ). There are negative correlations between soil properties of the average amount of clay $(p<0.01, R=-0.206)$ the average amount of $\operatorname{silt}(\mathrm{p}<0.01, \mathrm{R}=-0.247)$, field capacity $(\mathrm{p}<0.01, \mathrm{R}=-0.500)$, fine soil weight $(\mathrm{p}<0.05, \mathrm{r}=-0.179)$, soil reaction $(\mathrm{p}<0.01, \mathrm{r}=-0.575)$, and site index, while there are positive correlations between horizon $\mathrm{A}_{\mathrm{h}}$ 's organic matter $(\mathrm{p}<0.05, \mathrm{r}=0.340)$, the average amount of sand $(\mathrm{p}<0.01, \mathrm{r}=0.258)$, physiological soil depth $(\mathrm{p}<0.01, \mathrm{r}=0.212)$, skeleton weight $(\mathrm{p}<0.01, \mathrm{r}=0.197)$, and site index.
\end{abstract}

Keywords: Site index, moist ecosystem, slope, altitude, soil physical properties, Akkuş

\section{INTRODUCTION}

The growth of forest stands depends on their location in the stand and numerous factors including basic resources such as light, water, and nutrients the actual physical sizes of which can be reached. All these factors interact and change in space and time to be expressed together with the observed growth rate (Cienciala et al. 2016). This interaction and change take place in the form of a series of dynamic events different from its surroundings (matter and energy circulation and transformations) within the boundaries of an ecological unit called site. The effects of the factors that constitute the site on the formation of the characteristics of the site and site productivity are not similar. 
The silvicultural practices to be performed in forest ecosystems and the management plans require safe site productivity. The estimation of growth and product in forest ecosystems can be achieved by the accurate assessment of productivity. Despite the suitability of site productivity estimations developed for tree species in forest management (Fernández et al. 2004), the change of local ecological conditions species (edaphic, topographic, climatic) for the same tree may show a correlation contrary to estimations. Although the change of site productivity is determined depending on certain environmental conditions, it can also be evaluated within the conceptual framework of site quality as the characteristic vegetation production capacity of the field (Hägglund, 1981). Most of the site quality studies were carried out in even-aged stands (planted or naturally regenerated) (Herrera and Alvarado, 1998).

There are various methods to estimate the site quality/productivity, including those based on the measurement of the forest (Daubenmire, 1976; Clutter et al., 1983 ; Shafer, 1989; Schönau and Aldworth, 1991; Vanclay, 1994). However, the most frequently used method in even-aged stands is the estimation of the site index as a measure of productivity. The most commonly used and mostly accepted method to evaluate the actual site productivity and the growth reaction of trees in forestry is the measure of upper stand height reached at a certain age, which is known as site index (SI). The forest trees and undergrowth in forest ecosystems tend to be shaped according to (climate and soil conditions etc.) (Cajander 1949; Childs and Flint 1990; Sims et al. 1996; Wang and Klinka 1996; Salemaa et al. 2008). Therefore, the nutrition, thermal and hydrological regimes of the soil significantly affect the site productivity. The hydrological conditions of sites depend not only on the physical characteristics of the soil but also on the topographic position and ambient weather conditions (Childs and Flint 1990; Nyberg 1996; Mäkitalo 2009; Campbell et al. 2013). For forestry management, the effect of location factors (slope, aspect, altitude, topographic position) on the characteristics and productivity of forest areas cannot be ignored.

Site productivity is largely determined by the physical and chemical properties of the soil, however, it is also affected by climate factors such as precipitation, temperature and the length of the growing season. Both physical and chemical soil properties are used in soil-site methods to estimate the site productivity (Fontes et al. 2003, Stape et al. 2004, Sampson et al. 2008, Almeida et al. 2010, Vega-Nieva et al. 2013). When the physical, chemical and biological properties of the soil are used, site productivity/site quality is generally better estimated (Subedi and Fox, 2016).

Numerous soil-site studies attempted to associate the measured soil properties with the site index (SI) (Carmean 1975, Hagglund 1981, Bravo and Montero 2001, Fontes et al. 2003) Nevertheless, it is quite difficult to measure the site productivity/site quality from soil properties in forest ecosystems due to the complex correlations between stand productivity and soil properties. The site quality and stand productivity can be approached from a different perspective, and site factors can be considered as a function of geoclimatic variables (Pokharel and Froese 2009; Bontemps and Bouriaud 2014).

In soil-site studies, regression techniques were frequently used to estimate site productivity from the topographical and edaphic characteristics of a site (Carmean 1975, Baker and Broadfoot 1979, Wang 1995, Beaulieu et al. 2011). To estimate the SI by developing a regression equation only with soil properties is also another method. Along with the genetic characteristics and climate characteristics, soil as the source of both water and nutrients is the most important factor affecting the growth of trees. Both physical and chemical soil properties may affect tree height depending on the site conditions.

There are many studies investigating the correlations between the height growth of trees and site factors, in other words, the correlations between SI and site factors. In these studies, the correlations between the site factors of both naturally grown species (Klinka and Carter 1990; Kayhara et al. 1997; Günlü et al. 2006; Johansson 2006; Özkan and Kuzugüdenli 2010; Karataş et al. 2013; ) and the species brought to the area by planting (Curt et al. 2001; Sanchez -Rodriguez et al. 2002; Louw and Scholes 2005; Tüfekçioğlu et al. 2005; Yilmaz et al. 2008; Güner et al. 2011; Karataş and Özkan 2017 ) and site productivity was investigated. In this study, in the natural sites of oriental beech, which is one of the 
important tree species of Turkey, in Akkuş region of the Eastern Black Sea Region, the correlations between SI and site factors were investigated at altitude levels (1200-1500 m) where unique ecological conditions are dominant. Oriental beech ranks number two in terms of spread area and ranks number one in terms of the amount of growing stock among leafy species (1.96 million hectares). Approximately $41 \%$ of leafy normal high forests in Turkey consist of Oriental beech forests (Anonymous, 2015).

\section{MATERIAL AND METHOD}

The research area is geographically located in the Eastern Black Sea Section of the Black Sea Region. The sample plots were selected from Ordu-Akkuş region, from the west of the Eastern Black Sea section where pure Oriental beech ( forests are spread. Akkuş region, which is one of the places where the beech is optimally spread, is located within the fields that are under the influence of the sea and within CanikGiresun Mountains Site region (Kantarc1, 2005a) (Figure 1). Within the scope of the study, 40 sample plots were taken from Akkuş region (20 sample plots were used from Yilmaz 2005).

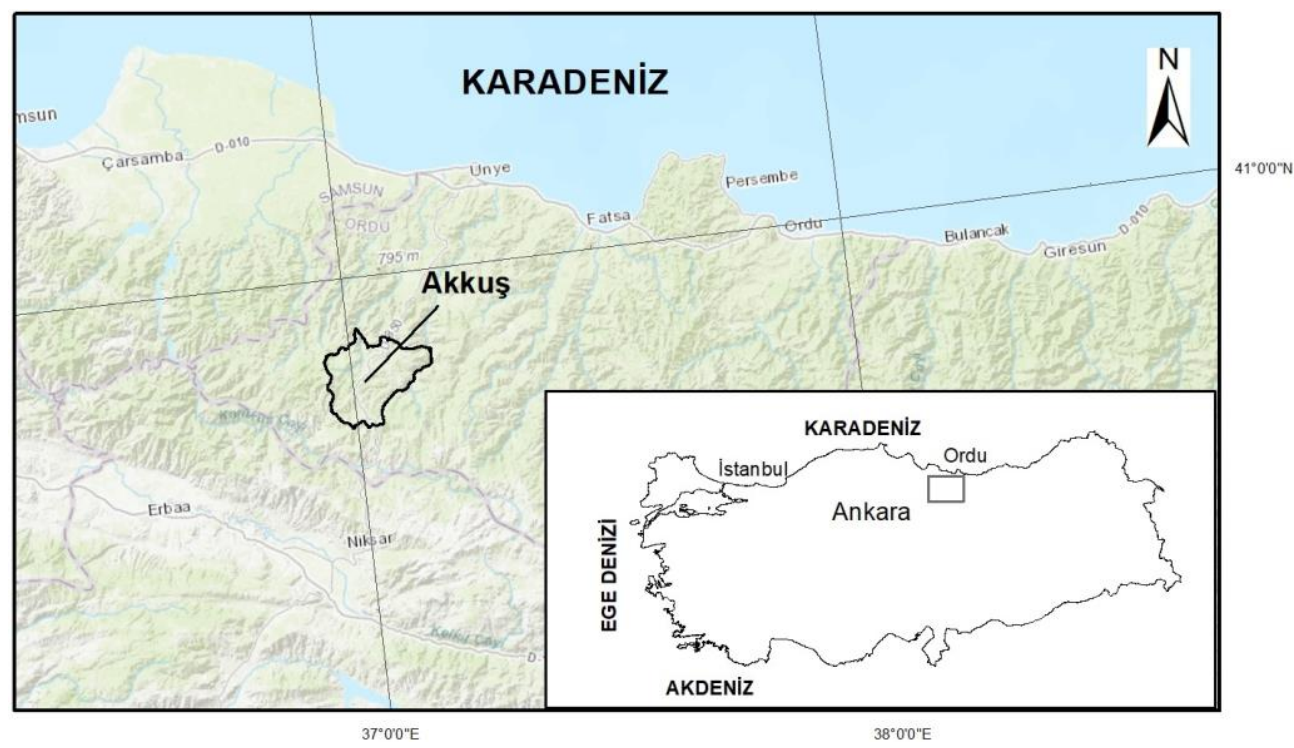

Figure 1. Location of the research area.

In Akkuş region surrounded by beech forests on all sides, the average annual amount of precipitation is $1092,9 \mathrm{~mm}$ and the average annual temperature is $7.9^{\circ} \mathrm{C}$. The average temperature in four summer months is $15.4{ }^{\circ} \mathrm{C}$ (Y1lmaz 2005). Since the mountain ranges in the region are parallel to the coastline, moist air masses bring plenty of precipitation in the region. The heights of the mountains and their positions against the prevailing north-west winds are more or less effective on the precipitation regime of the region. Furthermore, the river valleys crossing the mountain chains, which are parallel to the coastline, (Akçay, Cevizdere) ensure that the maritime climate is effective up to the interior parts. The climate analysis of Akkuş region was performed according to the Thornthwaite (1952) method, and it was determined as the "humid, high temperature (mesothermal) climate close to the oceanic climate with little or no water deficient" represented by the "B4 B'1 r b'4" symbol (Table 1).

There are totally 22649 hectares of pure Oriental beech forests in Akkuş region. 7350 hectares of this forest area is between 1200-1400 m altitudes while 8300 hectares of which is between 1000-1200 m altitudes. After $1400 \mathrm{~m}$, the area of beech forests decreases up to 2278 hectares (Anonymous, 2015). The average altitude and average slopes of the sample plots are $1330 \mathrm{~m}$ and $36 \%$, respectively, and they were taken from the soils developed from andesite-basalt bedrock. The dominant aspect of the sample plots is in the north aspect direction. 
The sample plots were taken from the boundaries of Akkuş Forestry Department Akkuş Forest Subdistrict Directorate. The average altitude of Akkuş region from sea level is 1313 meters and the horizontal distance from the sea is $75 \mathrm{~km}$. The district is almost surrounded by beech forests on all sides. There are significant amounts of beech forest areas within the boundaries of Göllüce, Salman and Düzdağ forest sub-district directorate.

Table 1. Climate analysis of the research area.

\begin{tabular}{|c|c|c|c|c|c|c|c|c|c|c|c|c|c|c|c|}
\hline \multirow{2}{*}{$\begin{array}{l}\text { Climate } \\
\text { variables }\end{array}$} & \multicolumn{11}{|c|}{ Months } & \multicolumn{4}{|c|}{ Vegetation period } \\
\hline & I & II & III & IV & V & VI & VII & VIII & IX & $\mathrm{X}$ & XI & XII & Inside & Outside & Annual \\
\hline TEMP $\left({ }^{\circ} \mathrm{C}\right)$ & $-2,6$ & $-1,6$ & 2,6 & 7,6 & 10,2 & 14,5 & 16,2 & 15,2 & 13,3 & 11,3 & 7,4 & 1,1 & 13,5 & & 7,9 \\
\hline PREP (mm) & 74,9 & 89,1 & 60,6 & 136,2 & 180,8 & 69,0 & 51,1 & 31,6 & 85,0 & 84,9 & 96,4 & 133,3 & 502,4 & 590,5 & 1092,9 \\
\hline $\mathrm{AE}(\mathrm{mm})$ & - & - & 13,7 & 43,0 & 64,6 & 92,7 & 104,8 & 84,2 & 70,4 & 55,2 & 31,4 & 4,6 & 471,8 & 92,7 & 564,5 \\
\hline $\mathrm{WD}(\mathrm{mm})$ & - & - & - & - & - & - & - & - & - & - & - & - & 0,0 & 0,0 & 0,0 \\
\hline WS( mm) & 74,9 & 89,1 & 46,9 & 93,2 & 116,2 & - & - & - & - & - & - & 108,1 & 116,2 & 412,1 & 528,4 \\
\hline $\operatorname{ARH}(\%)$ & 79,2 & 79 & 76,1 & 78,8 & 78,8 & 76,8 & 81,4 & 81,2 & 80,4 & 74,8 & 72,8 & 79,6 & 78,9 & 77,6 & 78,2 \\
\hline ACD & 11,5 & 12,5 & 12,5 & 16,0 & 19,5 & 15,5 & 18,0 & 20,5 & 12,5 & 8,5 & 16,5 & 15,0 & 92,5 & 86,0 & 178,5 \\
\hline AOD* & 14,0 & 13,0 & 13,5 & 10,5 & 9,0 & 8,5 & 9,5 & 8,0 & 11,5 & 11,5 & 8,5 & 14,0 & 58,0 & 73,5 & 131,5 \\
\hline PD & 10,5 & 9,5 & 10,0 & 15,0 & 15,0 & 8,0 & 8,0 & 5,0 & 9,5 & 11,0 & 8,0 & 11,0 & 56,5 & 64,0 & 120,5 \\
\hline FD & 0,5 & 1,5 & 3,0 & 1,0 & 0,0 & 2,0 & 1,0 & 0,0 & 0,5 & 1,0 & 0,5 & 0,5 & 4,5 & 7,0 & 11,5 \\
\hline
\end{tabular}

TEMP: Temperature, PREP: Precipitation, AE: Actual evapotranspiration, WD: Water deficiency, WS: Water surplus ARH: Average relative humidity, ACD: Average cloudy days, AOD: Average overcast days, PD: Precipitation days, FD: Foggy days, * : Fully covered sky

The sample plots were taken by selected sampling, and their sizes vary between 400 and $600 \mathrm{~m}^{2}$ according to the crown cover. After the boundaries of the sample plots were determined, the trees included in the sample area were numbered in a clockwise direction, and the root collar diameter and chest height diameter of all of them were measured. The height measurement was performed in all trees the diameter measurement of which was performed, and the age of the trees was determined by counting the increment from $0.30 \mathrm{~cm}$ height. Carus's (1998) site index yield table for even-aged beech forests was used for the productivity indexes of sample plots.

\section{Method}

\section{Soil Properties}

In the sample plots, soil profiles were dug and absolute and physiological soil depths were determined (Kantarc1, 2000). In the soil profile, mineral soil horizons were separated and introduced according to genetic soil horizons, and the soil samples were taken in two ways: bag sampling and volume sampling. The fine soil weight (gr/lt) and the skeleton weight (gr/lt) of soil samples were determined using the volume samples taken according to Kantarc1 2005b. 176 soil samples taken from sample plots were ground and sieved following air dried and weighed before and after the skeleton has been removed.

The particle size analysis of soil samples was performed according to the Bouyoucos hydrometer method, and the soil types were determined according to international texture classes (Gülçur, 1974; Karaöz, 1989a).

Soil reaction $(\mathrm{pH})$ : was measured by $\mathrm{pH}$ meter with a glass electrode. The soils were mixed with distilled water by $1: 2,5$ for actual acidity, and they were mixed with $1 \mathrm{~N} \mathrm{KCl}$ by 1:2,5 for potential acidity, they were kept overnight and then measured (Gülçur, 1974; Karaöz, 1989b; Kantarc1, 2005b). Organic carbon in the soil was determined by Walkley-Black wet burning method. The organic matter of the soil was calculated based on organic carbon (Gülçur, 1974; Kantarc1, 2005b). The available water capacity 
(AWC) of soil samples were calculated based on the differences of field capacity moisture and wilting point moisture values determined in soil moisture device with pressure table (Karaöz 1989a; Kantarc1, 2005b).

Location Factors

The altitudes of the sample plots selected within the scope of the research vary between $1230 \mathrm{~m}$ and $1485 \mathrm{~m}$ and their slopes vary between 5\% and 70\%, and the research area was divided into two altitudinal zones and four slope groups.

$\begin{array}{llccc}\text { Slope }(\%) & \text { Slope Class } & \text { Slope group } & \text { Altitude }(\mathrm{m}) & \text { Altitudinal zones } \\ (0-16) & \text { Low and moderately sloping } & \text { I } & 1200-1350 & \text { I } \\ (17-35) & \text { Moderately high sloping } & \text { II } & 1351-1500 & \text { II } \\ (35-58) & \text { Strongly sloping } & \text { III } & & \\ (>58) & \text { Steep } & \text { IV } & & \end{array}$

\section{Statistical analysis}

The simple correlation analysis was performed between the SI values of sample plots determined and the physiographical factors and soil properties of the site. SPSS package program was used for this process (SPSS 2015).

\section{RESULTS AND DISCUSSION}

$60 \%$ (24) of the sample plots are located in the $1^{\text {st }}$ altitudinal zone while $40 \%$ (16) of them are located in the $2^{\text {nd }}$ altitudinal zone.

The site indexes of the sample plots are significantly positively correlated with altitude despite a low correlation coefficient. In other words, an increase is observed in site indexes along with an increase in altitude in Akkuş region ( $\mathrm{p}<0.01, \mathrm{r}=0.211$ ) (Table 2). In the literature, it is generally thought that there is a decrease in site indexes along with an increase in altitude (Klinka et al. 1996; Klinka and Chen 2003; Y1lmaz 2005; Ercanlı et al. 2008; Socha 2008; Özkan and Kuzugüdenli 2010; Öztürk 2012; Yilmaz et al. 2015). Although there is no correlation between the height growth of forest stands and altitude in some studies (Kalay 1996; Y1lmaz 2005), there are also positive correlations between altitude and height growth (Özkan et al. 2005; Güner 2008). These differences between altitude and SI values can be explained depending on the altitude variation of the study area and the change of other site factors, as well as the ecological characteristics of tree species. In general, the climatic characteristics changing with increasing altitude also negatively affect the site conditions, and the productivity of forest trees decreases along with the shortening of the growing period. In a part of the study carried out by Yilmaz (2005), no correlation was found between altitude and the SI of Oriental beech in Akkuş region. Within the scope of the study, 30 sample plots were taken between 1230-1550 meters. This study was carried out by taking 40 sample plots from Oriental beech stands between 1200-1500 meters altitudes. These altitudes are the $2^{\text {nd }}$ altitudinal zone where Oriental beech spreads optimally. The $1^{\text {st }}$ altitudinal zone, where Oriental beech spreads optimally within the boundaries of Akkuş Forestry department, is between 1000-1200 meters (a forest area of 8300 hectares). The positive correlation between altitude factor and the SI of Oriental beech stands is specific to the studied altitude climate zone of Akkus region. The absence of temperature reduction that would shorten the growing period depending on the increasing altitude between 1230 meters and 1485 meters where sample plots were taken, and also the availability of sufficient moisture did not negatively affect the organic and inorganic decomposition. Along with the increase in altitude, the thickness of B horizon (TBH), thickness of A horizon (TAH), physiological soil 
depth (PSD) and excavation depth (ED) in soil profiles, and the increase in average amounts of silt and clay and the reduction in average amount of sand of soil samples confirm conclusion (Table 2, Table 3). Along with the increase in altitude, TBH ( $p<0.01, \mathrm{r}=203)$, TAH ( $<<0.05, \mathrm{r}=0.157)$, PSD $(\mathrm{p}<0.01$, $\mathrm{r}=0.480)$ and $\mathrm{ED}(\mathrm{p}<0.01, \mathrm{r}=0.339)$ increased, and increased PSD and ED increased the SI values $(\mathrm{p}<0.01, \mathrm{r}=0.212 ; \mathrm{p}<0.01, \mathrm{r}=0.268)$.

One of the most important site factors affecting the productivity of forest trees is the degree of slope. The SI values of forest trees decrease with an increase in the degree of slope (Sharma et al. 2012; Y1lmaz 2005; Kalay 1996; Ercanl1 et al. 2008; Yilmaz et al. 2015). In this study, the SI values of Oriental beech increased along with an increase in the degree of slope. There is a positive correlation between the degree of slope and SI values ( $\mathrm{p}<0.01, \mathrm{r}=0.438)$. This correlation coefficient was found to be $\mathrm{r}=0.262$ in the study carried out by Yilmaz (2005) in the region. However, the author stated that it was not very true to generalize this argument on the grounds that the sample plots in the good productivity class are represented in a small number. The positive correlation between SI and slope resulting from unique ecological conditions of Akkuş region was clarified by increasing the number of sample plots in less sloping areas. The fact that the generally known positive effect of low and moderately sloping bottom lands on productivity was found to be opposite in Akkuş region may be due to the weak and moderate drainage feature of the sample plots taken from low and moderately sloping lands. Since the mountain ranges in the region where the study was carried out are parallel to the coastline, moist air masses bring plenty of precipitation in the research area and its surroundings. Indeed, Akkuş region was characterized by "very humid, low-temperature climate type without water deficiency" (Y1lmaz 2005).

There is excess water in the soil during the vegetation period. Furthermore, during the vegetation period, moist and saturated air masses move towards low and moderately sloping fields over high sloping fields and accumulate over beech forests in these areas ( Figure 2).

The fact that the soil is saturated with water due to precipitation, low degree of slope and soil characteristics (particle size, skeleton, fine soil weight) and also the fact that transpiration does not occur in the stand the top roof of which is covered with moist air masses adversely affect the nutrition and growth relationships in trees. In these sites, suberization and mossiness occur in trees due to excess moisture ( Figure 3) In the fields with high slope and sufficient soil depth, uptake of water and nutrients from the soil is not interrupted since there is less water in the soil and photosynthesis organs are further exposed to the sun. Because Oriental beech prefers high sloping lands with well-drained, deep, permeable soils (Saatçioğlu 1979). There are significant correlations between SI values of Oriental beech and the soil properties of the site. There was a positive $(\mathrm{p}<0.01, \mathrm{r}=0.258)$ correlation between the particle diameter of soils and the average amount of sand and a negative $(\mathrm{p}<0.01, \mathrm{r}=-0.206$ and $\mathrm{p}<0.01$, $\mathrm{r}=-0.247$ ) correlation between average amounts of silt and clay, respectively. The increased amount of clay and silt and decreased amount of sand in soils lead to the development of finer textured soils. In the sites located in the region where there is adequate precipitation and the slope is low, the increase in silt and clay amounts of soils further worsen the poor drainage conditions. The SI values of the low sloping sample plots, where drainage is blocked and the formation of standing water was observed locally, were low. The fact that the most important factors affecting the productivity of Oriental beech forests in the region are moisture in the atmosphere during the vegetation period, water held in the soil, the blocked drainage and the degree of slope of the land is also supported by the results of other correlation analyses. When the results of the correlation analysis presented in Table 2 are examined, it is seen that there are negative correlations between SI values and moisture content $(\mathrm{p}<0.01, \mathrm{r}=-0.500)$ and fine soil weight $(\%)$ of the soils $(\mathrm{p}<0.05, \mathrm{r}=-0.180)$ in the field capacity, and there are positive correlations between skeletal part of the soils $(\%)(\mathrm{p}<0.05, \mathrm{r}=0.197)$. 
Table 2. Correlations between the SI and site factors

\begin{tabular}{|c|c|c|c|c|c|c|c|c|c|c|c|c|c|c|c|}
\hline & $\begin{array}{l}\text { ALT } \\
(\mathrm{m})\end{array}$ & $\begin{array}{l}\text { Slope } \\
(\%)\end{array}$ & $\begin{array}{l}\text { Sand } \\
(\%)\end{array}$ & $\begin{array}{l}\text { Silt } \\
(\%)\end{array}$ & $\begin{array}{l}\text { Clay } \\
(\%)\end{array}$ & $\begin{array}{l}\text { SW } \\
(\%)\end{array}$ & $\begin{array}{l}\text { FSW } \\
(\%)\end{array}$ & $\begin{array}{l}\mathrm{FC} \\
(\%)\end{array}$ & $\begin{array}{l}\mathrm{ED} \\
(\mathrm{cm})\end{array}$ & $\begin{array}{l}\text { PSD } \\
(\mathrm{cm})\end{array}$ & $\begin{array}{l}\text { TAH } \\
(\mathrm{cm})\end{array}$ & $\begin{array}{l}\text { TBH } \\
(\mathrm{cm})\end{array}$ & $\begin{array}{l}\mathrm{pH} \\
(\mathrm{KCl})\end{array}$ & $\begin{array}{c}\mathrm{pH} \\
\text { (Water } \\
\text { ) }\end{array}$ & $\begin{array}{c}\text { AHO } \\
\text { M } \\
(\%) \\
\end{array}$ \\
\hline SI (m) & $\begin{array}{r}, 211^{*} \\
*\end{array}$ & $\begin{array}{r}, 438^{*} \\
*\end{array}$ &, $258 * *$ &, $247 * *$ &, $206^{* * *}$ &, $197 * *$ &,$- 179 *$ &, $500 * *$ &, $268 * *$ &, $212 * *$ &, $212 * *$ &,- 055 &, 575 ** &, $331 * *$ &, $340 * *$ \\
\hline $\operatorname{ALT}(\mathrm{m})$ & & ,058 &, $377^{* *}$ &, $357^{* *}$ &, $293 * *$ &,- 031 & ,112 &,- 139 &, $339 * *$ &, $480^{* * *}$ &, $157 *$ & $\begin{array}{r}, 203 * \\
*\end{array}$ & ,198** &, $289 * *$ &,- 141 \\
\hline Slope (\%) & & &, $286^{* * *}$ & ,139 &, $337 * *$ &, $212 * *$ &, $206 * *$ &,- 024 & ,085 &,- 015 &, $321 * *$ &,- 053 & ,406** &, $355^{* * *}$ & ,099 \\
\hline Sand $(\%)$ & & & &, $806 * *$ &, $905 * *$ & ,193* &, $268 * *$ &, $416^{* *}$ &,- 102 &,- 101 &,- 082 &,- 042 &, 101 &, $267 * *$ &,- 046 \\
\hline Silt (\%) & & & & &, $488 * *$ &, $246^{-\bar{*}}$ &, $296 * *$ &, $372 * *$ & ,091 & ,063 & ,097 & ,038 &,- 096 &, $378 * *$ &,- 066 \\
\hline Clay $(\%)$ & & & & & &,- 122 &, $200 * *$ &, $364 * *$ & ,056 & ,090 & ,025 &, 041 &,- 083 &,- 123 & ,105 \\
\hline SW (\%) & & & & & & &, $952 * *$ &, $370 * *$ & ,042 & ,015 &, $225 * *$ &,- 048 &,- 045 & ,064 & ,002 \\
\hline FSW (\%) & & & & & & & &, $367 * *$ & ,008 & ,085 &, $167^{*}$ &, $186^{*}$ & ,029 &,- 072 & ,005 \\
\hline $\mathrm{FC}(\%)$ & & & & & & & & &, $211^{* *}$ &, $262 * *$ &, 120 &,- 069 & ,291** & ,134 &,- 039 \\
\hline $\mathrm{ED}(\mathrm{cm})$ & & & & & & & & & &, $612 * *$ &, $372 * *$ & $\begin{array}{r}, 349 * \\
*\end{array}$ &,- 139 &,$- 158^{*}$ &, $211 * *$ \\
\hline $\begin{array}{l}\mathrm{AWC} \\
(\mathrm{cm})\end{array}$ & & & & & & & & & & &, $408 * *$ & $\begin{array}{r}, 597 * \\
*\end{array}$ &,- 051 &,- 019 &, $298 * *$ \\
\hline $\begin{array}{l}\text { TAH }(\mathrm{cm}) \\
\text { TBH }(\mathrm{cm})\end{array}$ & & & & & & & & & & & &, $184^{*}$ & $\begin{array}{r}, 285 * * \\
-, 074\end{array}$ & $\begin{array}{r}, 273 * * \\
, 034\end{array}$ & $\begin{array}{r}, 200 * * \\
, 014\end{array}$ \\
\hline $\mathrm{pH}(\mathrm{KCl})$ & & & & & & & & & & & & & &, $825 * *$ &,- 063 \\
\hline pH(Water & & & & & & & & & & & & & & & ,040 \\
\hline
\end{tabular}

Table 3. Variation of the average SI and soil properties of the sample plots according to altitudinal zones.

\begin{tabular}{|c|c|c|c|c|c|c|c|c|c|}
\hline & Altitudinal zones & NSP & $\begin{array}{c}\text { Mean } \pm \\
\text { Std. Dev. }\end{array}$ & Min. & Max. & & $\begin{array}{c}\text { Mean } \pm \\
\text { Std. Dev. }\end{array}$ & Min. & Max. \\
\hline \multirow{2}{*}{$\mathrm{SI}(\mathrm{m})$} & $\mathrm{I}$ & 24 & $25,94 \pm 2,34$ & 20,40 & 29,30 & \multirow[b]{2}{*}{$\mathrm{ED}(\mathrm{cm})$} & $115,82 \pm 20,43$ & 60,00 & 140,00 \\
\hline & II & 16 & $25,53 \pm 2,43$ & 23,10 & 30,20 & & $119,39 \pm 8,2$ & 90,00 & 130,00 \\
\hline \multirow{2}{*}{ Sand $(\%)$} & $\mathrm{I}$ & 24 & $62,37 \pm 16,36$ & 36,00 & 91,00 & \multirow[b]{2}{*}{$\operatorname{PSD}(\mathrm{cm})$} & $91,75 \pm 25,11$ & 30,00 & 120,00 \\
\hline & II & 16 & $48,45 \pm 13,76$ & 26,00 & 86,00 & & $95,00 \pm 17,93$ & 60,00 & 115,00 \\
\hline \multirow{2}{*}{ Silt (\%) } & $\mathrm{I}$ & 24 & $17,09 \pm 7,36$ & 5,00 & 35,00 & \multirow{2}{*}{$\operatorname{ASD}(\mathrm{cm})$} & $73,76 \pm 17,99$ & 15,00 & 97,00 \\
\hline & II & 16 & $23,27 \pm 7,9$ & 5,00 & 37,00 & & $72,15 \pm 17,96$ & 23,00 & 92,00 \\
\hline \multirow{2}{*}{ Clay (\%) } & $\mathrm{I}$ & 24 & $20,85 \pm 10,74$ & 1,00 & 42,00 & \multirow{2}{*}{ TAH $(\mathrm{cm})$} & $18,07 \pm 4,38$ & 11,00 & 28,00 \\
\hline & II & 16 & $28,36 \pm 10,49$ & 9,00 & 49,00 & & $18,73 \pm 2,85$ & 15,00 & 23,00 \\
\hline \multirow{2}{*}{ FSW (\%) } & I & 24 & $84,06 \pm 13,11$ & 33,54 & 99,00 & \multirow{2}{*}{$\mathrm{TBH}(\mathrm{cm})$} & $29,44 \pm 11,94$ & ,00 & 52,00 \\
\hline & II & 16 & $85,73 \pm 13,26$ & 50,91 & 98,95 & & $33,21 \pm 13,02$ &, 00 & 50,00 \\
\hline \multirow{2}{*}{$\mathrm{SW}(\%)$} & $\mathrm{I}$ & 24 & $15,94 \pm 13,11$ & 1,00 & 66,46 & \multirow{2}{*}{$\mathrm{pH}(\mathrm{KCl})$} & $4,50 \pm 0,48$ & 3,60 & 5,40 \\
\hline & II & 16 & $14,27 \pm 13,26$ & 1,05 & 49,09 & & $4,43 \pm 0,33$ & 3,80 & 5,20 \\
\hline \multirow{2}{*}{$\mathrm{FC}(\%)$} & I & 24 & $32,24 \pm 6,62$ & 14,17 & 43,20 & \multirow{2}{*}{$\mathrm{pH}$ (Water) } & $5,36 \pm 0,57$ & 4,10 & 6,40 \\
\hline & II & 16 & $32,90 \pm 4,71$ & 21,80 & 42,24 & & $5,14 \pm 0,43$ & 4,40 & 5,90 \\
\hline \multirow{2}{*}{ WP (\%) } & $\mathrm{I}$ & 24 & $21,25 \pm 5,3$ & 9,33 & 31,67 & \multirow{2}{*}{ AHOM (\%) } & $7,33 \pm 2,99$ & 3,78 & 14,17 \\
\hline & II & 16 & $23,51 \pm 4,38$ & 14,62 & 30,92 & & $5,61 \pm 0,82$ & 4,52 & 7,45 \\
\hline \multirow{2}{*}{ AWC (\%) } & $\mathrm{I}$ & 24 & $10,99 \pm 4,16$ & 2,73 & 30,14 & \multirow{2}{*}{$\mathrm{OM}(\%)$} & $3,02 \pm 2,98$ &, 23 & 14,17 \\
\hline & II & 16 & $9,39 \pm 2,74$ & 4,30 & 14,76 & & $2,91 \pm 1,88$ &, 47 & 7,45 \\
\hline
\end{tabular}

NSP: Number sample plot, SI: Site index, FSW: fine soil weight, S: Skeleton weight, FC:Field capacity, WP: Wilting point, AWC: available water capacity, ED: Excavation depth, PSD: Physiological soil depth, ASD: Absolute soil depth, TAH: Thickness of A horizon, TBH: Thickness of B horizon, AHOM: Amount of organic matter of A horizon, OM: Organic matter

The moisture content in the field capacity of the soils corresponds to the equivalent moisture retained in capillary pores after leachate leach out of the soil. In fact, it is the moisture equivalent to the upper limit of water retained by capillarity in the soil. While it is considered by some scientists as a value close to the maximum capacity of capillary water and normal capillarity moisture terms (Irmak, 1972), it is considered by some scientists as the maximum moisture content that can be retained in the root zone soil of free-draining soils (Özhan, 2004). The negative correlation between the SI values and the moisture contents in field capacity means a reduction in the productivity of Oriental beech depending on the increase in the amount of water retained in the capillary pores of soils. Oriental beech, which prefers deep and well aired and drained soils, is not well developed in these sites. The fact that capillary pores are saturated with water for a long period of time also negatively affects the aeration in time. 


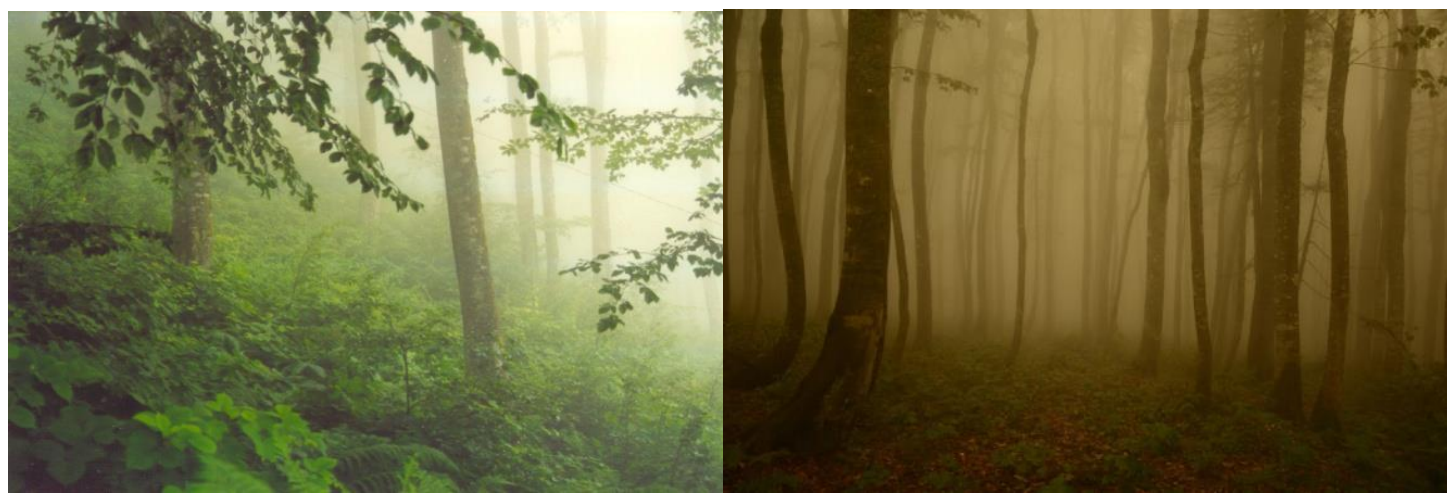

Figure 2. Top roof covering of the stand by moist air masses in the research area.

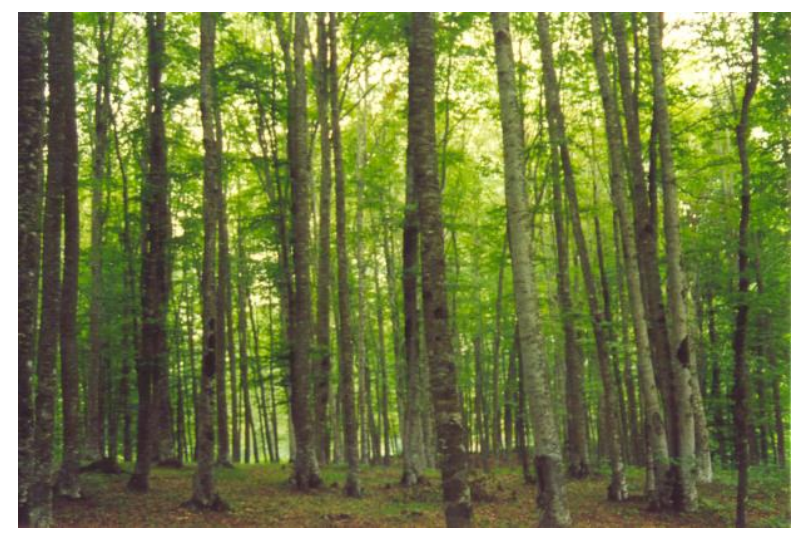

Figure 3. Mossiness in trees in Oriental beech stands on flat grounds.

The positive correlation between the SI of Oriental beech and the amount of skeleton of soils can be partially explained by the fact that the soil skeleton positively affects the productivity by allowing aeration. Because the percolation of the water is accelerated, drainage becomes easier and aeration increases in the sites where the skeleton part of the soil is more. However, it is usual to expect a negative correlation between the amount of skeleton and the site indexes in the sites where the average skeleton reaches $60-70 \%$ (Y1lmaz 2005)

Increased fine soil weight in soils slows down percolation, complicates drainage and reduces aeration. In the research area, while the lowest fine soil section varies between $50.91 \%$ and $68.47 \%$ in the low and moderately sloping sample plots, the lowest fine soil section varies between $33.54 \%$ and $45.92 \%$ in high and steep sloping fields. In this region, the reduction of the fine soil weight, and the increase in skeleton weight in terms of facilitating aeration and drainage in the soil increased the productivity of forest trees. However, this can be said for the low sloping sample plots of the research area where the soil depth is sufficient, dominated by the moderately fine textured soils with no lack of water and nutrients.

One of the physical soil properties affecting the productivity of forest trees is the soil depth. Soil depths are known as physiological depth, absolute depth, and excavation depth. In general, the productivity of forest trees increase with increasing soil depths (Çepel ve ark., 1977; Daşdemir 1987; Kalay 1989; Leblanc 1994; Y1lmaz 2005; Karataş et al. 2013; Paulo et al. 2014; Güner et al. 2016). 
Table 4. Variation of site indexes and soil properties according to slope groups

\begin{tabular}{|c|c|c|c|c|c|c|c|c|c|}
\hline & SG & NSP & $\begin{array}{c}\text { Mean } \pm \\
\text { Std. Dev }\end{array}$ & Min. & Max. & & $\begin{array}{c}\text { Mean } \pm \\
\text { Std. Dev }\end{array}$ & Min. & Max. \\
\hline \multirow{4}{*}{$\mathrm{SI}(\mathrm{m})$} & I & 8 & $25,28 \pm 1,32$ & 23,60 & 27,30 & \multirow{4}{*}{$\mathrm{ED}(\mathrm{cm})$} & $122,38 \pm 4,31$ & 120,00 & 130,00 \\
\hline & II & 12 & $23,81 \pm 2,17$ & 20,40 & 26,60 & & $112,61 \pm 18,67$ & 60,00 & 130,00 \\
\hline & III & 10 & $27,04 \pm 1,45$ & 24,70 & 28,90 & & $110,95 \pm 25,55$ & 60,00 & 140,00 \\
\hline & IV & 10 & $27,07 \pm 2,52$ & 23,10 & 30,20 & & $122,61 \pm 6,81$ & 120,00 & 140,00 \\
\hline \multirow{4}{*}{ Sand $(\%)$} & I & 8 & $69,52 \pm 15,58$ & 41,00 & 91,00 & \multirow{4}{*}{ PSD (cm) } & $93,48 \pm 20,44$ & 65,00 & 120,00 \\
\hline & II & 12 & $48,82 \pm 13,31$ & 32,00 & 86,00 & & $93,04 \pm 25,15$ & 30,00 & 120,00 \\
\hline & III & 10 & $53,19 \pm 14,31$ & 36,00 & 75,00 & & $95,57 \pm 18,92$ & 60,00 & 110,00 \\
\hline & IV & 10 & $57,22 \pm 16,86$ & 26,00 & 87,00 & & $90,04 \pm 25,42$ & 50,00 & 115,00 \\
\hline \multirow{4}{*}{ Silt (\%) } & I & 8 & $15,90 \pm 7,50$ & 5,00 & 32,00 & \multirow{4}{*}{ ASD (cm) } & $78,14 \pm 5,62$ & 70,00 & 84,00 \\
\hline & II & 12 & $22,41 \pm 7,37$ & 5,00 & 36,00 & & $69,43 \pm 26,76$ & 15,00 & 92,00 \\
\hline & III & 10 & $20,38 \pm 7,99$ & 6,00 & 37,00 & & $68,19 \pm 16,58$ & 47,00 & 97,00 \\
\hline & IV & 10 & $18,96 \pm 8,43$ & 5,00 & 35,00 & & $76,87 \pm 13,50$ & 63,00 & 97,00 \\
\hline \multirow{4}{*}{ Clay (\%) } & I & 8 & $14,57 \pm 9,28$ & 1,00 & 33,00 & \multirow{4}{*}{ TAH (cm) } & $20,48 \pm 4,45$ & 17,00 & 28,00 \\
\hline & II & 12 & $28,82 \pm 11,06$ & 9,00 & 47,00 & & $18,83 \pm 2,54$ & 14,00 & 21,00 \\
\hline & III & 10 & $26,95 \pm 8,73$ & 10,00 & 42,00 & & $17,50 \pm 3,56$ & 12,00 & 22,00 \\
\hline & IV & 10 & $24,17 \pm 10,31$ & 8,00 & 49,00 & & $16,57 \pm 3,73$ & 11,00 & 23,00 \\
\hline \multirow{4}{*}{ FSW (\%) } & I & 8 & $89,60 \pm 6,54$ & 68,47 & 96,93 & \multirow{4}{*}{ TBH (cm) } & $35,57 \pm 11,34$ & 25,00 & 52,00 \\
\hline & II & 12 & $86,44 \pm 12,47$ & 50,91 & 98,95 & & $28,04 \pm 15,91$ &, 00 & 50,00 \\
\hline & III & 10 & $83,56 \pm 16,17$ & 33,54 & 99,00 & & $28,05 \pm 8,04$ & 19,00 & 40,00 \\
\hline & IV & 10 & $79,56 \pm 13,77$ & 45,92 & 95,45 & & $31,87 \pm 11,55$ & 16,00 & 50,00 \\
\hline \multirow{4}{*}{ AS (\%) } & I & 8 & $10,40 \pm 6,54$ & 3,07 & 31,53 & \multirow{4}{*}{$\mathrm{pH}(\mathrm{KCl})$} & $4,69 \pm 0,34$ & 4,10 & 5,20 \\
\hline & II & 12 & $13,56 \pm 12,47$ & 1,05 & 49,09 & & $4,66 \pm 0,40$ & 4,00 & 5,40 \\
\hline & III & 10 & $16,44 \pm 16,17$ & 1,00 & 66,46 & & $4,18 \pm 0,26$ & 3,80 & 4,80 \\
\hline & IV & 10 & $20,44 \pm 13,77$ & 4,55 & 54,08 & & $4,37 \pm 0,47$ & 3,60 & 5,20 \\
\hline \multirow{4}{*}{$\mathrm{FC}(\%)$} & I & 8 & $32,19 \pm 7,07$ & 14,17 & 43,11 & \multirow{4}{*}{$\mathrm{pH}$ (Water) } & $5,58 \pm 0,52$ & 4,80 & 6,40 \\
\hline & II & 12 & $34,31 \pm 5,00$ & 21,80 & 43,20 & & $5,38 \pm 0,46$ & 4,40 & 5,90 \\
\hline & III & 10 & $30,84 \pm 4,85$ & 17,14 & 37,49 & & $4,99 \pm 0,46$ & 4,10 & 5,90 \\
\hline & IV & 10 & $32,53 \pm 6,32$ & 17,45 & 42,24 & & $5,17 \pm 0,51$ & 4,40 & 6,10 \\
\hline \multirow{4}{*}{ WP (\%) } & I & 8 & $22,22 \pm 5,08$ & 11,44 & 31,67 & \multirow{4}{*}{$\operatorname{AHOM}(\%)$} & $6,73 \pm 2,43$ & 4,37 & 9,32 \\
\hline & II & 12 & $24,13 \pm 5,21$ & 13,05 & 30,30 & & $5,84 \pm 0,79$ & 5,09 & 8,56 \\
\hline & III & 10 & $20,41 \pm 2,82$ & 12,36 & 24,67 & & $7,92 \pm 3,81$ & 3,98 & 14,17 \\
\hline & IV & 10 & $21,63 \pm 5,95$ & 9,33 & 30,92 & & $6,31 \pm 1,86$ & 3,78 & 8,90 \\
\hline \multirow{4}{*}{$\mathrm{AWC}(\%)$} & I & 8 & $9,97 \pm 3,93$ & 2,73 & 19,10 & \multirow{4}{*}{ OM (\%) } & $2,58 \pm 2,53$ & 32 & 9,32 \\
\hline & II & 12 & $10,18 \pm 4,91$ & 4,51 & 30,14 & & $3,07 \pm 2,20$ & 47 & 8,56 \\
\hline & III & 10 & $10,43 \pm 3,62$ & 4,30 & 17,17 & & $3,51 \pm 3,27$ &, 57 & 14,17 \\
\hline & IV & 10 & $10,90 \pm 2,20$ & 6,49 & 15,26 & & $2,77 \pm 2,37$ & 23 & 8,90 \\
\hline
\end{tabular}

SG: Slope groups, NSP: Number sample plot, SI: Site index, FSW: fine soil weight, AS: Amount skeleton, FC:Field capacity, WP: Wilting point, AWC: available water capacity, ED: Excavation depth, PSD: Physiological soil depth, ASD: Absolute soil depth, TAH: Thickness of A horizon, BHK: Thickness of B horizon, AHOM: Amount of organic matter of A horizon, OM: Organic matter

In this study, there were positive correlations between the site index values and soil depths $(\mathrm{p}<0.01$, $\mathrm{r}=0.212$ with physiological soil depth; $\mathrm{p}<0.01, \mathrm{r}=0.268$ with excavation depth) (Table 2). However, the low correlation coefficient is remarkable. The fact that soil depths show a lower correlation than the other soil properties is specific to this site. For the research area, the average absolute soil depth is 74 $\mathrm{cm}$, the physiological soil depth is $91 \mathrm{~cm}$ and the excavation depth is $117 \mathrm{~cm}$ (Table 4). There is no restriction related to soil depth in terms of the nutrition of plants.

Another edaphic factor affecting the productivity of forest trees is the soil reaction. Soil reaction may have different degrees of effects on growth of trees depending on tree species, tree age, climatic conditions, and other ecological conditions. In addition to positive correlations between soil reaction and the SI values of trees (Brown 2007; Yilmaz et al. 2015), negative correlations (Yilmaz et al. 2008; Yilmaz et al. 2015) were also mentioned. In natural spread area, Oriental beech forests grow in soils with degrees between $4.1-6.0 \mathrm{pH}(\mathrm{NKCl})$ (Çepel 1995) and 3.5 - $6.6 \mathrm{pH}(\mathrm{NKCl})$ (Yılmaz 2005), 4.88 $-5.35 \mathrm{pH}\left(\mathrm{H}_{2} \mathrm{O}\right)$ (Sariyildiz et al. 2005; Sariyildiz and Küçük 2009). In this study, there was a significant negative correlation between soil reaction $(\mathrm{pH})(\mathrm{NKCl})$ and the SI values of Oriental beech $(\mathrm{p}<0.01, \mathrm{r}=-$ $0.575)$, the average soil reaction was $4.47 \mathrm{pH}(\mathrm{NKCl})$, and average limit values varied between $3.60-$ 
$5.40 \mathrm{pH}(\mathrm{NKCl})$. The increase in $\mathrm{pH}$ between these limit values decreases the SI values. In the research area, the sample plots where the SI values are low are the low sloping sample plots. It is interesting that the average $\mathrm{pH}$ values of low sloping sample plots are higher (Table 4). It is known that $\mathrm{Al}^{+3}$ and $\mathrm{H}^{+}$ ions in the soil cause low soil $\mathrm{pH}$ and that other cation (such as $\mathrm{Ca}^{+2}, \mathrm{Mg}^{+2}$ ) cause high $\mathrm{pH}$. In the research area, the changeable $\mathrm{Ca}^{+2}$ and $\mathrm{Mg}^{+2}$ amounts of the sample plots with high $\mathrm{pH}$ values are lower than those of the sample plots with low $\mathrm{pH}$ values and high SI values. The correlation between soil $\mathrm{pH}$ and SI may be due to the effect of nutrient uptake. Since transpiration from plant leaves will decrease in the sites with high air humidity like the research area, the groundwater will not be absorbed by plant roots and especially the leaves will not get the cations such as $\mathrm{Ca}^{+2}$. It is reported that fungi develop in leaves that cannot get enough $\mathrm{Ca}^{+2}$ (Kantarc1 2000). Since the development of leaves is adversely affected and the leaf surface area will decrease in sample plots with high $\mathrm{Ca}^{+2}$ and high $\mathrm{pH}$, photosynthesis will be adversely affected and the SI values will decrease.

\section{CONCLUSION}

Site productivity is determined by the local ecological conditions (climatic, edaphic and topographic) of the site, along with the genetic characteristics of species. While site productivity is generally expected to decrease with an increase in some spatial factors such as land slope and altitude, productivity may increase when evaluated together with other local ecological conditions (climatic and hydrological). In this study, a similar correlation was revealed under local site conditions in Akkuş region of Eastern Black Sea Region of Turkey. It is quite interesting that SI decreases along with a decrease in altitude and the degree of slope of the field in Akkuş region, which is one of the optimum sites of Oriental beech in Turkey. It is very important to know the correlations between such sites and productivity for forestry practices to be performed and planned management organizations. The time and forms of the interventions to be performed to forest ecosystem at a limited elevation belt (1200-1500 m) and under certain topographical and edaphic conditions (flat and low slope, fine-textured soils) and the interventions to be performed in the sites with regional ecological conditions (high slope, hillsides and areas with high altitudes) may be different. Because the SI and the amount of above-ground biomass of the same tree species will be different in the two different sites described. Therefore, the time of intervention to the forest ecosystem will change. Furthermore, the areas of usage of forest products to be produced from these sites may also change. For instance, the properties of wood produced in humid sites and the properties of wood produced in very humid-wet sites will be different. To know the local ecological characteristics of the site well in the afforestation and natural regeneration studies in potential areas will provide a basis for the management of similar areas.

\section{References}

Almeida, A.C., Siggins, A., Batista, T.R., Beadle, C., Fonseca, S., Loos, R. (2010). Mapping the effect of spatial and temporal variation in climate and soils on Eucalyptus plantation production with 3PG, a process -based growth model. Forest Ecology and Management, 259 (9), 1730-1740.

Anonymous. (2015). Republic of Turkey General Directorate of Forestry, Türkiye Orman Envanteri.

Baker, J.B., Broadfoot, W.M. (1979). A practical field method of site evaluation for commercially important southern hardwoods. USDA For. Serv., Genetic Technical Report SO, 26, Southern Forest Experimental Station, New Orleans, LA. 51 p.

Beaulieu, J., Raulier F., Pr'egent, G., Bousquet, J. (2011). Predicting site index from climatic, edaphic, and stand structural properties for seven plantation-grown conifer species in Quebec. Can. J. For. Res. 41(4), 682- 693.

Bontemps, J.D., Bouriaud, O. (2014). Predictive approaches to forest site productivity: recent trends, challenges and future perspectives. Forestry $87,109-128$.

Bravo, F., Montero, G. (2001). Site index estimation in scots pine (Pinus sylvestris L.) stands in the High Ebro Basin (northern Spain) using soil attributes. Forestry 74(4), 395- 406. 
Brown, J.H. (2007). Growth and site index of White Pine in correlation to soils and topography in the glaciated areas of Ohio, Northern Journal of Applied Forestry, 24 (2), 98-103.

Carmean, W. (1975). Forest site quality evaluation in the United States. Adv Agron 27, 209-269.

Carus, S. (1998). Aynı yaşlı doğu kayını (Fagus orientalis Lipsky.) ormanlarında artım ve büyüme, İ. Ü. Fen Bilimleri Enstitüsü, İstanbul, 202 s. (Doktora tezi).

Cajander, A.K. (1949). Forest types and their significance. Acta Forestalia Fennica 56. 71 p. https:// doi.org/10.14214/aff.7396.

Campbell, D.M.H., White, B., Arp, P.A. (2013). Modeling and mapping soil resistance to penetration and rutting using LiDAR-derived digital elevation data. Journal of Soil and Water Conservation, 68(6), 460-473.

Childs, S.W., Flint, A.L. (1990). Physical properties of forest soils containing rock fragments. In: Gessel S.P., Lacate D.S., Weetman G.F., Powers R.F. (eds.). Sustained productivity of forest soils. Proceedings of the 7th North American Forest Soils Conference. University of British Columbia, Faculty of Forestry Publication, Vancouver B.C. p. $95-121$.

Cienciala, E., Russ, R., Šantrůčková, H., Altman, J., Kopáček, J., Hůnová, I., Štěpánek, P., Oulehle, F., Tumajer, J., Ståhl, G. (2016). Discerning environmental factors affecting current tree growth in Central Europe. Science of the Total Environment, 573, 541-554.

Clutter, J., Fortson, J., Pienaar, L., Brister, H., Bayley, R. (1983). Timber management: a quantitative approach. John Willey \& Sons, New York. 333 pp.

Corona, P., Scotti, R., Tarchiani, N. (1998). Relationship between environmental factors and site index in Douglasfir plantations in central Italy. Forest Ecology and Management 110(1-3), 195-207.

Curt, T., Bouchaud, M., Agrech, G. (2001). Predicting site index of Douglas fir plantations from ecological variables in the Massif Central are of France. Forest Ecology Management 149, 61-74.

Çepel, N., Dündar, M., Günel, A., (1977). Türkiye'nin önemli yetişme bölgelerinde saf sarıçam ormanlarının gelişimi ile bazı edafik ve fizyografik etmenler arasındaki ilişkiler. Tübitak Yayınları, Yayın No: 354/65, Ankara.

Çepel, N., (1995). Orman Ekolojisi, İ. Ü. Yayınları, Üniversite Yayın No: 3886, İstanbul.

Daubenmire R., 1976. The use of vegetation in assessing the productivity of forest lands. Bot Rev 42:2, 115-143.

Ercanli, İ., Günlü, A., Altun L., Baskent, Z.E. (2008). Relationship between site index of oriental spruce (Picea orientalis (L.) Link) and ecological variables in Maçka Turkey. Scandinavian Journal of Forest Research. 23(4), $319-329$.

Fernández, B.H., Campos, J.J., Kleinn, C. (2004). Site productivity estimation using height-diameter relationships in Costa Rican secondary forests. Invest Agrar: Sist Recur For. 13 (2), 295-303.

Fontes, L., Tom'e, M., Thompson, F., Yeomans, A., Lu1s, J.S. and Savill, P. 2003. Modelling the douglas-fir (pseudotsuga menziesii (mirb.) Franco) site index from site factors in portugal. Forestry 76(5):491-507.

Gülçur, F. 1974: Toprağın Fiziksel ve Kimyasal Analiz Metotları, İ.Ü.Yayın No: 1970, Orm. Fak. Yayın No:201, Kutulmuş Matbaası, İstanbul.

Güner, Ş.T. (2008). Bozkıra geçiş bölgesindeki sarıçam (Pinus sylvestris L. ssp. hamata (Steven) Fomin.) ormanlarının gelişimi ile bazı yetişme ortamı özellikleri arasındaki ilişkiler. Eskişehir. Çevre ve Orman Bakanlı̆̆ı. Orman Toprak ve Ekoloji Araştırmaları Enstitüsü Müdürlügü Yayını. Bakanlık Yayın No: 358. Müdürlük Yayın No: $3.41 \mathrm{~s}$.

Güner, Ş.T., Çömez, A., Karataş, R., Çelik, N., Özkan, K. (2011). Eskişehir ve Afyonkarahisar illerindeki anadolu karaçamı (Pinus nigra Arnold. subsp. pallasina (Lamb.) Holmboe) ağaçlandırmalarının gelişimi ile bazı yetişme ortamı özellikleri arasındaki ilişkiler. Çevre ve Orman Bakanlığı, Orman Toprak ve Ekoloji Araştırmaları Enstitüsü Müdürlüğü Yayını, Bakanlık Yayın No: 434, Müdürlük Yayın No: 4, 83 s.

Güner, Ş.T., Çömez, A., Özkan, K., Karataş, R., Çelik, N. (2016). Türkiye'deki karaçam ağaçlandırmalarının verimlilik modellemesi. Journal of the Faculty of Forestry Istanbul University 66(1): 159-172. DOI: 10.17099/jffiu.18731.

Günlü, A., Yılmaz, M., Altun, L., Ercanlı, İ., Küçük, M. (2006). Artvin genya dağı bölgesinde saf doğu ladini (Picea orientalis (L) Link.) meşcerelerinin verimliliği ile bazı edafik ve fizyografik faktörler arasındaki ilişkiler. SDÜ Orman Fakültesi Dergisi, Seri A, 1, 1-10 
Hagglund, B. (1981). Evaluation of forest site productivity. For. Abstr.42, 515-527.

Herrera, B., Alvarado, A. (1998). Calidad de sitio y factores ambientales en bosques de Centro América. Rev Agron Costarricense 22 (1), 99-117.

Irmak, A, 1972. Toprak İlmi. İÜ Orman Fak. Yay. No 184, İstanbul.

Johansson, T. (2006). Site index conversion equations for Picea abies and five broadleaved species in Sweden: Alnus glutinosa, Alnus incana, Betula pendula, Betula pubescens and Populus tremula. Scandinavian Journal of Forest Research, 21(1),14 - 19.

Kalay, Z. (1989). Trabzon Orman Bölge Müdürlüğü mıntıkasında saf doğu ladini (Dorukağaç) (Picea orientalis (L.) Link.) büklerinin gelişimi ile bazı toprak özelliklerinin ve fizyografik etmenlerin arasındaki ilişkilerin denel olarak araştırılması. Karadeniz Teknik Üniversitesi. Orman Fakültesi. Doçentlik Tezi. Trabzon.

Kantarc1, M.D. (2000). Toprak İlmi, İkinci Baskı, İ.Ü. Orman Fakültesi Yayınları, İ.Ü. Yayın No: 4261, O .F.Y ayın No: 462, Syf: 420, İstanbul.

Kantarcı, M.D. (2005a). Türkiye'nin Yetişme Ortamı Bölgesel Sınıflandırması ve Bu Birimlerdeki Orman Varlığı ile Devamlılı̆̆ının Önemi, İ.Ü.Yay. No: 4558, Orm. Fak. Yay. No: 484, İstanbul.

Kantarc1, M. D. (2005b). Orman Ekosistemleri Bilgisi, İ.Ü. Yayın No: 4594, Orman Fakültesi Yayın No: 488, (XXVI+418), İstanbul Üniversitesi Basım ve Yayınevi Müdürlüğü, ISBN: 975- 404-756-1, İstanbul.

Karaöz, M.Ö. (1989a) Toprakların su ekonomisine ilişkin bazı fiziksel özelliklerinin laboratuvarda belirlenmesi yöntemleri, İstanbul Üniversitesi Orman Fakültesi, 39(2), 133-144.

Karaöz, M.Ö. (1989b) Toprakların bazı kimyasal özelliklerinin (pH, karbonat, tuzluluk, organik madde, total azot, yararlanılabilir fosfor) analizi yöntemleri). İstanbul Üniversitesi Orman Fakültesi, Seri B 39: 64-82.

Karataş, R., Arslan, M., Güner, Ş.T., Çömez, A., Özkan, K. (2013). Göller Bölgesindeki Doğal Yayılış Alanlarında Kasnak Meşesinin (Quercus vulcanica Boiss. and Heldr. Ex Kotschy) Boy Gelişimi ile Yetişme Ortamı Özellikleri Arasındaki İlişkiler. T.C. Orman ve Su İşleri Bakanlığı. Orman Genel Müdürlügüü. Orman Toprak ve Ekoloji Araştırmaları Enstitüsü Müdürlüğü Yayın No: 9/5. Eskişehir.

Karataş, R., Özkan, K. (2017). Toros sediri (Cedrus libani A. Rich.) ağaçlandırmalarının gelişimi İle yetişme ortamı özellikleri arasındaki ilişkiler, Orman Genel Müdürlüğü Ormancılık Araştırma Dergisi, 1(4): 12-21 DOI: https://doi.org/10.17568/ogmoad.302425.

Kayahara, G.J., K. Klinka, and A.C. Schroff. 1997. The relationship of site index to synoptic estimates of soil moisture and nutrients for western redcedar (Thuja plicata) in southern coastal British Columbia. Northwest Science 71,167-173.

Klinka, K., Wang, Q., Carter, R.E., Chen, H.Y.H. (1996). Height growth_elevation relationships in subalpine forests of interior British Columbia. Forestry Chronicle. 72, 193-198.

Klinka, K., Carter, R.E. (1990). Relationships between site index and synoptic environmental factors in immature coastal Douglas-fir stands. For. Sci. 36, 815-830.

Klinka, K., Chen. H.Y H. (2003). Potential productivity of three interior subalpine forest tree species in British Columbia. Forest Ecology and Management. 175, 521-530.

Leblanc, P.A. (1994). Soil-Site Relations for Jack Pine (Pinus banksiana Lamb.) in Northeastern Ontarı, Lakehead Üniversitesi (Canada), Yüksek Lisans Tezi.

Louw, J.H., Scholes , M.C. (2005). Site index functions using site descriptors for Pinus patula plantations in South Africa. Forest Ecology and Management 225, 94-103

Mäkitalo, K. (2009). Soil hydrological properties and conditions, site preparation, and the long term performance of planted Scots pine (Pinus sylvestris L.) on upland forest sites in Finnish Lapland. Dissertationes Forestales 80. 71 p.https://doi.org/10.14214/df.80

Nyberg, L. (1996). Spatial variability of soil water content in the covered catchment at Gårdsjön, Sweden. Hydrological Processes 10(1), 89-103.

Özhan, S. (2004). Havza Amenajmanı. İstanbul Üniversitesi Orman Fakültesi, Yayın no: 482, İstanbul.

Özkan, K., Gülsoy, S., Mert, A. (2005). Interrelations between height growth and site characteristics of Pinus nigra Arn. ssp. pallasiana (Lamb.) Holmboe. J. The Malaysian Forester. 71: 9-16. 
Özkan, K., Kuzugüdenli, E. (2010). Akdeniz bölgesi sütçüler yöresinde kızılçamın (Pinus brutia ten.) verimliliği ile yetişme ortamı özellikleri arasındaki ilişkiler. Süleyman Demirel Üniversitesi Orman Fakültesi Dergisi Seri: A. 1, 16-29.

Paulo, J.A., Palma, J.H.N., Gomes, A.A. (2015). Predicting site index from climate and soil variables for cork oak (Quercus suber L.) stands in Portugal. New Forests 46(2), 293-307.

Pokharel, B., Froese, R.E. (2009). Representing site productivity in the basal area increment model for FVSOntario. Forest Ecology and Management 258, 657-666.

Saatçioğlu, F. (1979). Silvikültür II. İ.Ü. Orman Fakültesi Yayınları No:172

Salemaa, M., Derome, J., Nöjd, P. (2008). Response of boreal forest vegetation to the fertility status of the organic layer along a climatic gradient. Boreal Environment Research, 13, 48-66.

Sampson, D.A., Wynne, R.H., Seiler, J.R. (2008). Edaphic and climatic effects on forest stand development, net primary production, and net ecosystem productivity simulated for Coastal Plain loblolly pine in Virginia. Journal of Geophysical Research: Biogeosciences 113(G1),1-14.

Sanchez-Rodriguez, F., Rodríguez-Soalleiro, R., Español, E., López, C.A., Merino, A. (2002). Influence of edaphic factors and tree nutritive status on the productivity of Pinus radiata D. Don plantations in Northwestern Spain, Forest Ecology and Management, 171,181-189.

Sariyildiz, T., Küçük, M. (2009). Infuence of slope position. stand type and rhododendron (Rhododendron ponticum) on litter decomposition rates of Oriental beech (Fagus orientalis Lipsky.) and spruce (Picea orientalis (L.) Link). Eur J Forest Res. 128, 351-360

Sariyildiz, T,. Tüfekçioğlu, A., Küçük, M. (2005). Comparison of decomposition rates of beech (Fagus orientalis lipsky) and spruce (Picea orientalis (L.) Link) litter in pure and mixed stands of both species in Artvin. Turkey. Turk J Agric For 29, 429-438

Schöau, A.P., Aldworth, W.J.K. (1991). Site evaluation in black wattle with special reference to soils factors. S Afr For J, 156, 35-43.

Shafer, G.N. (1989). Site indicator species for predicting productivity of pine plantations in the southern Cape. S Afr For J, 147, 7-17.

Sharma, R.P., Brunner, A., Eid, T. (2012). Site index prediction from site and climate variables for Norway spruce and Scots pine in Norway. Scand. J. For. Res. 27, 619-636

Sims, R., Baldwin, K., Kershaw, M., Wang, Y. (1996). Tree species relation to soil moisture regime in northwestern Ontario, Canada. Environmental Monitoring and Assessment 39(1-3), 471-484.

Socha, J. (2008) .Effect of topography and geology on the site index of Picea abies in the West Carpathians. Poland. Scandinavian Journal of Forest Research. 23, 203-213.

SPSS, M. O. D. (2015): SPSS (Statistical Package for the Social Sciens).

Stape, J.L., Ryan, M.G., Binkley, D. (2004). Testing the utility of the 3 -PG model for growth of Eucalyptus grandis $x$ urophylla with natural and manipulated supplies of water and nutrients. Forest Ecology and Managment, 93 (1-2),219-234.

Subedi, S., Fox, T.R. (2016). Predicting loblolly pine site index from soil properties using partial least-squares regression. Forets Science, 62, 449-456.

Tüfekçioğlu, A., Altun, L., Kalay, H.Z., Yılmaz, M. (2005). Effects of some soil properties on the growth of hybrid poplar in the Terme-Gölardı region of Turkey, Turk J Agric For, 29, 221- 226.

Vanclay, J. (1994). Modelling Forest Growth and Yield; Applications to Mixed Tropical Forest. CAB International, Wallingford, U.K. 336p.

Vega -Nieva, D.J., M. Tomé, J. Tomé, L. Fontes, P. Soares, L. Ortiz, F. Basurco, and R. Rodrígez -Soalleiro. (2013). Developing a general method for the estimation of the fertility rating parameter of the 3-PG model: application in Eucalyptus globulus plantations in northwestern Spain. Canadian. Journal of Forest Research 43(7),627-636.

Wang, G., Klinka, K. (1996). Classification of moisture and aeration regimes in sub-boreal forest soils. Environmental Monitoring and Assessment, 39 (1-3), 451-469. 
Wang, G.G. (1995). White spruce site index in relation to soil, understory vegetation, and foliar nutrients. Canadian Journal of Forest Research, 25(1), 29 -38.

Yılmaz, M. (2005). Doğu Karadeniz bölümü saf doğu kayını ekosistemlerinde kimi ortam etmenlerinin kayının gelişimine etkileri üzerine araştırmalar. KTÜ Fen Bilimleri Enstitüsü. Orman Mühendisliği Anabilim Dalı. Yayımlanmamış Doktora Tezi. Trabzon. 188 s.

Yilmaz, M., Çicek, E., Tonguç, F. , Yilmaz, S. (2009). Relationships between seedling height growth and some soil properties in Douglas Fir (Pseudotsuga menziesii Var. viridis) plantations. Journal of Applied Biological Sciences 3, 17-22.

Yilmaz, M., Usta, A., Öztürk, İ. (2015). Relationships between site indices and ecological factors for balck alder stands in Turkish eastern black sea region. Fresenius Environmental Bulletin, 24 (4), 1285-1293. 